\title{
Project Financing of German Universities as an Instrument for Improving their Competitiveness among the World's Leading Scientific and Educational Centers
}

\section{Financiamiento de proyectos de universidades alemanas como instrumento para mejorar su competitividad entre los principales centros científicos y educativos del mundo}

\author{
Olga Alekseevna Grishina \\ Plekhanov Russian University of Economics, Moscow, Russia \\ https://orcid.org/0000-0001-9033-8555 \\ Zhanneta Ilijasovna Gerzelieva \\ Plekhanov Russian University of Economics, Moscow, Russia \\ https://orcid.org/0000-0003-1387-0593 \\ Tatyana Nikolaevna Rodenkova \\ Plekhanov Russian University of Economics, Moscow, Russia \\ https://orcid.org/0000-0002-5185-3076 \\ Elena Ivanovna Gromova \\ Plekhanov Russian University of Economics, Moscow, Russia \\ https://orcid.org/0000-0001-5499-0853
}

*Correspondencia

Email: grishina.oa@rea.ru 


\section{Summary}

Higher education institutions present key social institutions ensuring the creation and transfer of knowledge, intellectual capital, and innovations. This fact determines the significance of universities in state regulation and allocating financial resources to the best of them is becoming a crucial objective in many countries. Goals of the article is to study of the German Excellence Initiative project. The study identifies the characteristics of the Excellence Initiative project. A set of indicators of the project effectiveness is presented and the positive effects and problems of the project are indicated. Directions for the development of the European Universities' project financing system are proposed. Project financing allowed changing the organizational structure of the German science system. However, it is necessary to continue the search for various cooperation formats and the ways for the development of gifted researchers in the scientific sphere, strengthen the universities' prestige and infrastructure, and further improve the project financing models. Institutional strategies are aimed at strengthening the positions of a university overall allowing it to successfully compete with the leading participants in the international scientific arena. An institutional strategy requires a university to develop a longterm policy of consistent expansion and improvement of the quality of its research and promotion of young scientists and researchers allowing to identify the existing strengths and set priorities.

Keywords: Project Financing, Financial Resources, Higher Education Institution, University, Germany.

\section{Introduction}

In the early 2000s, despite appearing in international rankings of the best universities, German universities did not take high positions in them due to insufficient competitiveness. Moreover, there was a significant disruption in the interaction between universities and research institutes preventing synergy and benefits to universities (Grishina et al.: 2020; Mackey et al.: 2017). In 2005, the German federal government in association with the constituent entities of the country launched the Academic Excellence Initiative project involving the allocation of significant additional funding and awarding a prestigious title of "University of Excellence" to successful universities. The goals of the project include:

1) improving academic studies;

2) increasing the popularity and the general level of German universities in the global arena (Audretsch et al.: 2015);

3) stimulating competition in scientific research between universities;

4) promoting cooperation between universities, industrial partners, and society (Catania et al.: 2019).

The basis of the project was formed by the idea of competition to identify the best universities and develop them further (Klarl et al.: 2016). This approach was revolutionary and differed from the ideal of equality and treating all universities in the same way that was predominant at the time (Carbo-Valverde et al.: 2016). Although German universities were gradually modernized through the formation of a new public management structure and increased financing not contingent on results, the Academic Excellence Initiative introduced a completely different level. The project changed the fundamental paradigm in the scientific and educational policy of Germany - the preceding "equality paradigm" was outplaced by the "differentiation paradigm" (Kosov et al.: 2018; Weigmann: 2015; Koschitchki, Patatoukas: 2014; Moller et al.: 2016).

\section{Materials and Methods}

The examined project implied financing in three areas: graduate school for young researchers, "excellence clusters" - centers for the development of interdisciplinary and socially 
important research, and the "concepts of the future" (or institutional strategies) for promoting high-quality research in German universities and increasing their international competitiveness. To receive financing from the third program, a university had to have a history of previous funding for at least one graduate school and one "excellence cluster" (Coshen, Dean: 2005; Morozova et al.: 2020).

The goal of graduate schools was to activate the promotion of young scientists and researchers and improve the level of their scientific studies. This goal was achieved by creating a favorable research environment to train highly qualified doctoral students. Each graduate school included various scientific directions solving innovative tasks and was led by leading scientists in the area. Ensuring optimal conditions for obtaining a doctoral degree, a graduate school stimulates doctoral students to perceive it as their Alma mater and further contribute to the development of internationally competitive research centers.

Excellence clusters integrate research potential in German universities and, therefore, increase their international popularity and competitiveness. The main objective of such institutions is ensuring scientific cooperation in the research field in the present and the future. Excellence clusters comprise universities, non-university research institutions, and industrial partners. For universities, excellence clusters present an important component of strategic planning and accelerate the process of prioritizing particular directions of research.

\section{Results}

The Excellence Initiative was implemented by the German Research Foundation in collaboration with the German Science Council and had two stages which included three stages of financing - in 2006, 2007-2008, and 2012-2017. The initial budget of the project was 1.9 billion euros and in 2012 the funding was increased by 2.7 billion euros with $75 \%$ of additional funding being allocated from the federal budget and $25 \%$ being contributed from regional ones (Civera et al.: 2020; Kosov et al.: 2016). All funds were spent exclusively on scientific research. The first stage consisted of two rounds held in 2005/2006 and 2006/2007 and each of them included a preliminary and final stage (Fig. 1).

In the course of the preliminary rounds, universities were submitting their applications which were examined by the groups of international experts. Expert evaluations of the applications for graduate schools and "excellence clusters" were provided by the expert commission composed of 14 people appointed by the German Research Foundation. The selection of applications for "institutional strategies" was conducted by the strategic commission from the German Science Council composed of 12 members. The preliminary selection was conducted by the unified commission which combined the expert and the strategic commissions. The universities selected at this stage later provided more detailed proposals evaluated through a procedure similar to the preliminary selection. The projects for financing were then selected by the grants committee presenting a unified commission of federal and regional ministers of science and research.

During the first round, 319 applications submitted by 74 universities were examined. By the final stage, 90 proposals remained (39 graduate schools, 41 excellence clusters, 10 institutional strategies). On October 13, 2006, the grants committee selected 38 proposals from 22 universities (18 graduate schools, 17 excellence clusters, and 3 institutional strategies) for financing totaling 873 million euros. 
Figure (1): The procedure of selecting universities for financing within the framework of the Excellence Initiative project

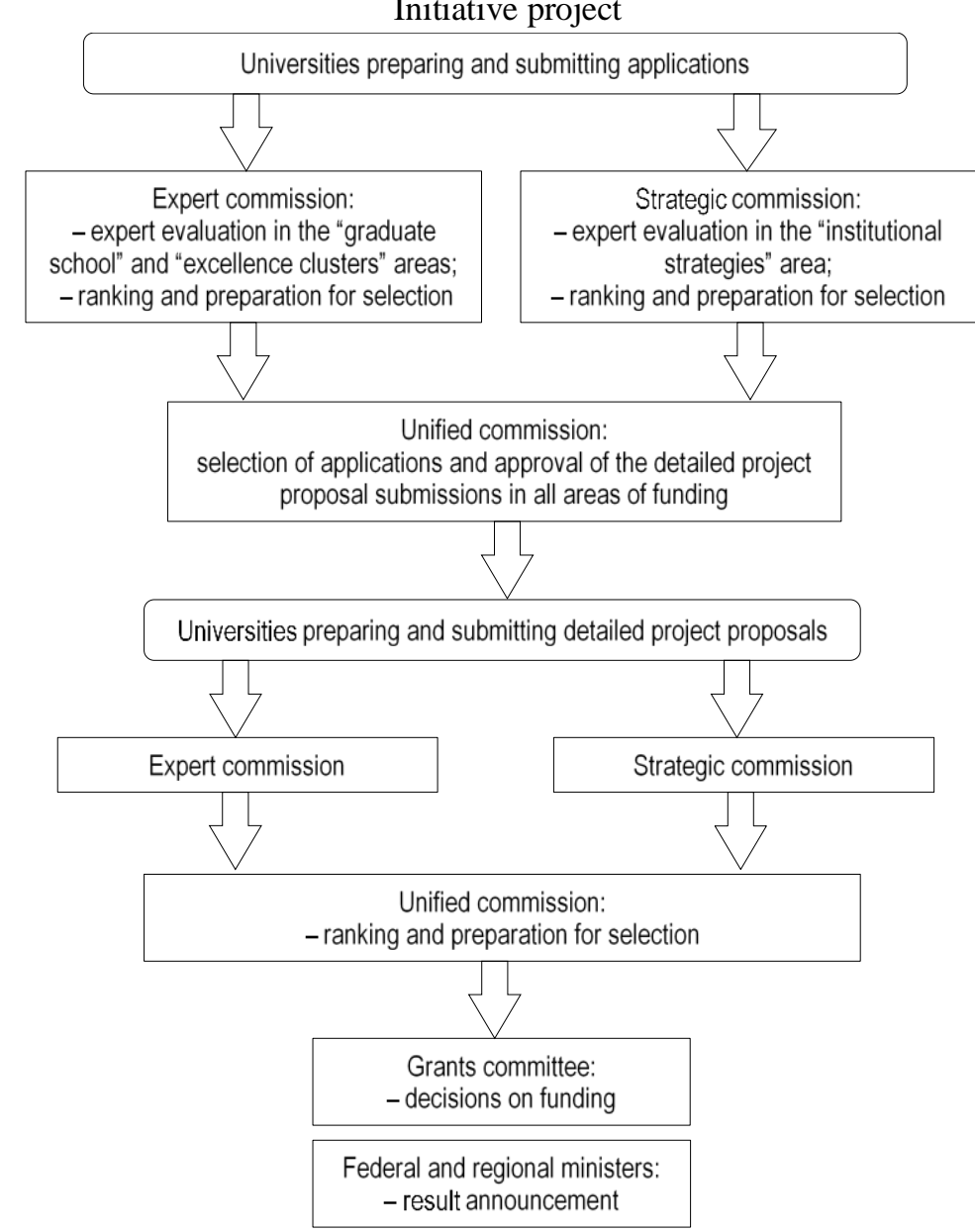

In the second round, the project received 305 applications, 92 of which (44 graduate schools, 40 excellence clusters, 8 institutional strategies) entered the final stage of the competition. The grant committee selected 47 applications from 28 universities (21 graduate schools, 20 excellence clusters, and 6 institutional strategies) for financing totaling 1 billion euros (Abdullah, Najib: 2016; Kosov et al.: 2017).

The main objective of the second stage was to create competition between the new projects and the ones already receiving funding. The second stage consisted of only one round which was also divided into the preliminary and final rounds.

The funding conditions at the second stage of the project differed from the ones at the first stage in that the determined amounts of funding were more flexible: from 1 to 2.5 million euros a year for graduate schools and from 3 to 8 million euros for excellence clusters (including the added $20 \%$ of funding per program). Institutional strategies have placed greater emphasis on the elements of research-related teaching. At the second stage, 99 proposals from 44 universities were selected for funding: 45 graduate schools (33 renewed, 12 new) totaling about 60 million euros annually, 43 excellence clusters (31 renewed, 12 new) totaling 253 million euros annually, and 11 institutional strategies (6 renewed, 5 new) worth 145 million euros per year (Daskalakis et al.: 2017). The universities that were successful in the "concepts of the future" direction were awarded the title of "Universities of Excellence" and received additional 70 million euros over the next five years. 


\section{Conclusion}

The analysis of the results of the Excellence Initiative project implementation by the indicators of effectiveness (the ratio of allocated financial resources to the following parameters - the number of graduates, citations, and patents), the number of conducted studies (the number of publication per teacher), and the quality of research (the ratio of citations to publications) demonstrates that universities that joined the project demonstrate better results and growth in said indicators (Fig. 2). The number of publications increased by $32 \%$ and citation rates grew by $55 \%$.

Figure (2): The Excellence Initiative project effectiveness (FAQ - Excellence Strategy: 2019)

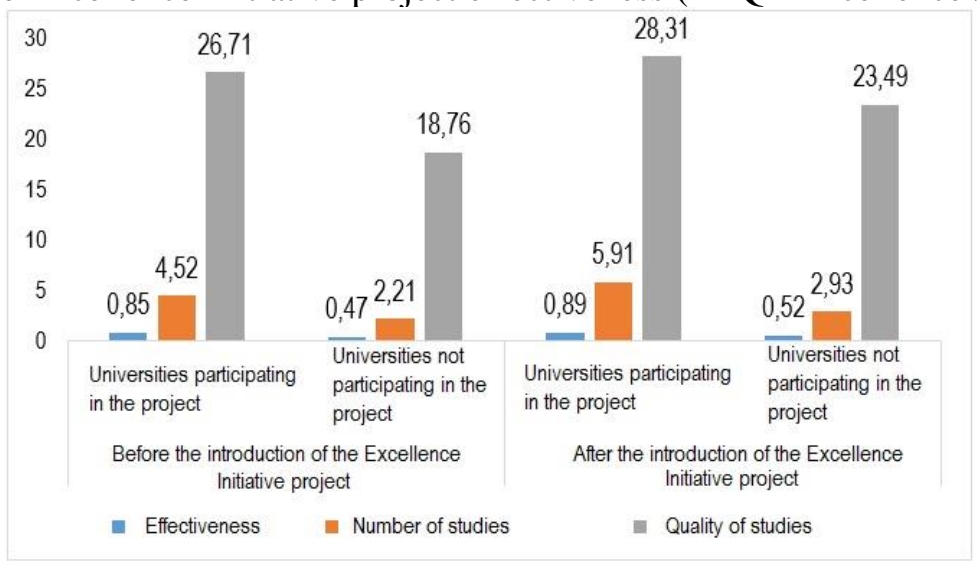

Financial resources allocated as a part of the project were spent by the universities on remunerations to researchers, investments, and purchases of consumables (Fig. 3). The major part of funds $(63 \%)$ was spent on paying for research work. The project involved 18,700 scientists 5,800 of whom were funded directly from the budget of the project.

Figure (3): Distribution of financial resources by universities within the framework of the Excellence Initiative project (Alipour et al.: 2018)

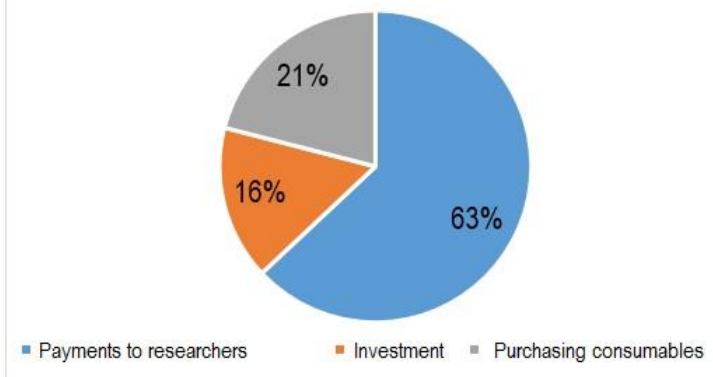

The Academic Excellence Initiative project affected both the German system of higher education and the development of scientific research in universities (Table 1).

Table (1): Effects of the Excellence Initiative project

\begin{tabular}{|l|l|}
\hline $\begin{array}{l}\text { Influence of the program on the German } \\
\text { higher education system }\end{array}$ & $\begin{array}{l}\text { Influence of the program on the development of } \\
\text { the system of scientific research in universities }\end{array}$ \\
\hline $\begin{array}{l}\text { the allocation of additional funding for } \\
\text { university research }\end{array}$ & $\begin{array}{l}\text { the creation of bigger structures ensuring } \\
\text { collaboration between different disciplines, } \\
\text { institutions, and industries }\end{array}$ \\
\hline $\begin{array}{l}\text { the creation of about 4,000 new job positions } \\
\text { for researchers }\end{array}$ & the implementation of flexible budgets \\
\hline $\begin{array}{l}\text { increased autonomy and flexibility of } \\
\text { universities }\end{array}$ & systemic quality assurance \\
\hline
\end{tabular}




\begin{tabular}{|l|l|}
\hline $\begin{array}{l}\text { increased internationalization and } \\
\text { international attractiveness }\end{array}$ & professional management \\
\hline $\begin{array}{l}\text { increased competition and cooperation } \\
\text { between universities and research } \\
\text { organizations }\end{array}$ & $\begin{array}{l}\text { various time limits for concluding contracts } \\
\text { with teachers }\end{array}$ \\
\hline $\begin{array}{l}\text { increased publicity of universities and } \\
\text { information awareness of the results of their } \\
\text { studies }\end{array}$ & $\begin{array}{l}\text { the strengthening and expansion of the network } \\
\text { of postgraduate programs and schools }\end{array}$ \\
\hline $\begin{array}{l}\text { increased opportunities for female scientists } \\
\text { the stimulation of the differentiation of } \\
\text { universities and their structures }\end{array}$ & $\begin{array}{l}\text { the launch of dual-career programs and } \\
\text { childcare services }\end{array}$ \\
\hline
\end{tabular}

Despite the range of positive aspects of the project, it is necessary to indicate particular problems that emerged in the course of its implementation:

a) universities faced difficulties in implementing the required large-scale projects (Crosonqvist et al.: 2012);

b) the five-year funding period was often not enough to reach the declared result (Dorofeyev et al.: 2018);

c) the future of universities after the end of funding remains unclear including the fate of the new staff of specialists (Cunningham et al.: 2019; Khedhaouria et al.: 2015);

d) difficulties in balancing research and teaching (Fauver, McDonald: 2015);

e) a decrease in the consumer rating and the demand for universities not included in the project;

f) the lack of clear methodology in evaluating the effectiveness of such projects (Kosrajczyk, Levy: 2003).

At the same time, the successful realization of the Academic Excellence Initiative project received its continuation in the modified version titled Excellence Strategy. The goals of the new project remained quite close to the initial ones - ensuring stable development of German science through improving competitiveness in the international arena; strengthening universities by stimulating and supporting high-quality research and cooperation in the sphere of science; conducting cutting-edge research and improving the quality of higher education and science in Germany.

Financial resources are allocated for research activities along two lines of funding "excellence clusters" (project financing of the areas of research that are competitive in the international arena in individual universities or the groups of collaborating universities) and "Universities of Excellence" (financing the development of universities or groups of cooperating universities, as well as their positions in scientific research at the global level). In this case, the funding is permanent. The prerequisite for receiving funding as a University of Excellence is the previously received funding for two or more excellence clusters (three or more for the groups of collaborating universities).

Since 2018, 533 million euros are allocated annually to fund the project including 385 million euros for the first line of financial support of the excellence clusters and 148 million euros for the second line - the Universities of Excellence. The funds are distributed between the federal budget and regional budgets in a ratio of 75 to 25 . Moreover, the period of financing grew up to 7 years (Iqbal, Kume: 2019; Noseleit: 2013).

Overall, project financing of universities allowed changing the organizational structure of the German scientific system. Universities have begun to work more actively on the issues of self-identification and image prioritizing graduate schools, research, and management. The level and productivity of scientific research and interaction with business and society have increased (Cosombo, Grilli: 2005). On the other hand, the realization of the project is accompanied by a 
significant rise in competition which can eventually threaten a healthy climate in the educational and scientific environment. Short funding periods do not always allow for the planned changes to be carried out before the next round and also lead to long-term studies being abandoned. Obtaining the status of the University of Excellence raises the reputation of the university while being deprived of this title leads to negative consequences in an even greater amount. For instance, being included in the list of elite universities did not affect the number of applicants in a university in Baden-Württemberg significantly and being excluded from this list had a significant negative effect (Acosta-Alba et al.: 2012; Acs et al.: 2014).

The project financing effectiveness criteria remain unclear (Frietsch et al.: 2017). Concerning the indicator of publication activity, the share of German publications in the extended version of the Reuters Science Citation Index slightly decreased along with the countries of the USA and Europe while the share of developing countries (China, Brazil, India) grew (Cheney et al.: 2014; Mira, Patrick: 2014). The number of publications per scientist has remained relatively unchanged over the past years, as well as German scientists' citation rates.

Therefore, in the past decade, Germany has reached significant results in strengthening and improving the research base after introducing project financing of universities. However, it is necessary to continue the search for ways for gifted scientists' development in the scientific sphere and improving the prestige and infrastructure of universities. These objectives may be achieved through larger amounts of funding and continued reform of the education and science system.

\section{Acknowledgments}

The study was completed with the financial support of the Plekhanov Russian University of Economics.

\section{References}

Abdullah, L., Najib, L. (2016). Sustainable energy planning decision using the intuitionistic fuzzy analytic hierarchy process: choosing energy technology in Malaysia. International Journal of Sustainable Energy, 35(4): 360-377.

Acosta-Alba, I., Lopez-Ridaura, S., Werf, H., Leterme, P., Corson, M. (2012). Exploring sustainable farming scenarios at a regional scale: An application to dairy farms in Brittany. Journal of Cleaner Production, 28: 160-167.

Acs, Z.J., Autio, E., Szerb, L. (2014). National systems of entrepreneurship: Measurement issues and policy implications. Research Policy, 43(3): 476-494.

Alipour, M, Zare, K, Seyedi, H. (2018). A multi-follower bilevel stochastic programming approach for energy management of combined heat and power micro-grids. Energy, 149, 135-146.

Audretsch, D.B., Belitski, M., Desai, S. (2015). Entrepreneurship and economic development in cities. The Annals of Regional Science, 55(1): 33-60.

Carbo-Valverde, S., Rodriguez-Fernández, F., Udell, G.F. (2016). Trade credit, the financial crisis, and SME access to finance. Journal of Money, Credit and Banking, 48(1), 113-143. https://doi.org/10.1111/jmcb.12292

Catania, L., Grassi, S., Ravazzolo, F. (2019). Forecasting cryptocurrencies under model and parameter instability. International Journal of Forecasting, 35(2): 485-501.

Cheney, G., Santa Cruz, I., Peredo, A.M., Nazareno, E. (2014). Worker cooperatives as an organizational alternative: challenges, achievements and promise in business governance and ownership. Organization, 21(5): 591-603.

Civera, A., Lehmann, E., Paleari, S., Stockinger, S. (2020). Higher education policy: Why hope for quality when rewarding quantity?. Research Policy, 49(8): 25-32.

Coshen, B.D., Dean, T.J. (2005). Information asymmetry and investor valuation of IPOs: Top management team legitimacy as a capital market signal. Strategic Management Journal, 26(7): 683-690. 
Cosombo, M.G., Grilli, L. (2005). Founders' human capital and the growth of new technology-based firms: A competence-based view. Research Policy, 34(6): 795816.

Crosonqvist, H., Makhija, A.K., Yonker, S.E. (2012). Behavioral consistency in corporate finance: CEO personal and corporate leverage. Journal of Financial Economics, 103(1): 20-40.

Cunningham, J.A., Lehmann, E.E., Menter, M., Seitz, N. (2019). The impact of university focused technology transfer policies on regional innovation and entrepreneurship. The Journal of Technology Transfer, 44(5): 1451-1475.

Daskalakis, N., Balios, D., Dalla, V. (2017). The behaviour of SMEs' capital structure determinants in different macroeconomic states. Journal of Corporate Finance, 46: 248-260. https://doi.org/10.1016/j.jcorpfin.2017.07.005

Dorofeyev, M., Kosov, M.E., Ponkratov, V., Masterov, A., Karaev, A., Vasyunina, M. (2018). Trends and prospects for the development of blockchain and cryptocurrencies in the digital economy. European Research Studies Journal, 21(3): 429-445.

FAQ - Excellence Strategy. (2019). Retrieved from: https://www.bmbf.de/files/FAQ\%20english\%20Excellence\%20Strategy\%20Last\%2 Oupdated\%20July\%202019\%20.pdf

Fauver, L., Mcdonald, M. (2015). Culture, agency costs, and governance: International evidence on capital structure. Pacific-Basin Finance Journal, 34: 1-23.

Frietsch, R., Schubert, T., Rothengatter, O. (2017). An analysis of the Excellence Initiative and its effects on the funded universities. Studien zum deutschen Innovations system 11-2017. Berlin: Expertenkommission Forschung und Innovation (EFI) Commission of Experts for Research and Innovation.

Grishina, O.A., Gerzelieva, Z.I., Shibaev, S.R., Minkhazetdinova, K.Z. (2020). The experience of financial support of European universities for their sustainable development. Journal of Advanced Research in Dynamical and Control Systems, 12(3): 1263-1269.

Iqbal, A., Kume, O. (2019). Impact of financial crisis on firms' capital structure in UK, France, and Germany. Multinational Finance Journal, 18(3/4): 249- 280. https://doi.org/10.17578/18-3/4-3

Khedhaouria, A., Gurău, C., Torrès, O. (2015). Creativity, self-efficacy, and small-firm performance: the mediating role of entrepreneurial orientation. Small Business Economics, 44(3): 485-504.

Klarl, T., Lehmann, E.E., Menter, M. (2016). In Search of Excellence: A Case Study of the First Excellence Initiative of Germany. Retrieved from SSRN: https://ssrn.com/abstract=2832605

Koschitchki, Y., Patatoukas, P.N. (2014). Accounting earnings and gross domestic product. Journal of Accounting and Economics, 57: 76-88.

Kosov, M.E., Akhmadeev, R.G., Osipov, V.S., Kharakoz, Y.K., Smotritskaya, I.I. (2016). Socio-economic planning of the Economy. Indian Journal of Science and Technology, 9(36).

Kosov, M.E., Akhmadeev, R.G., Smirnov, V.M., Popkov, S.Y., Rycova, I.N. (2017). Hydrocarbon market in countries with developing economy: Development scenario. International Journal of Energy Economics and Policy, 7(6): 128-135.

Kosov, M.E., Akhmadeev, R.G., Smirnov, D.A., Solyannikova, S.P., Rycova, I.N. (2018). Energy industry: Effectiveness from innovations. International Journal of Energy Economics and Policy, 8(4): 83-89.

Kosrajczyk, R.A., Levy, A. (2003). Capital structure choice: Macroeconomic conditions and financial constraints. Journal of Financial Economics,68(1): 75-109.

Mackey, T.B., Barney, J.B., Dotson, J.P. (2017). Corporate diversification and the value of individual firms: A Bayesian approach. Strategic Management Journal, 38(2): 322341.

Mira, F., Patrick, K. (2014). Effects of the German Universities' Excellence Initiative on Ability Sorting of Students and Perceptions of Educational Quality. Cologne 
Graduate School Working Paper Series 05-01, Cologne Graduate School in Management, Economics and Social Sciences, revised 25 Jun 2016.

Moller, T., Schmidt, M., Hornbostel, S. (2016). Assessing the effects of the German Excellence Initiative with bibliometric methods. Scientometrics, 109(3): 2217-2239.

Morozova, T., Akhmadeev, R., Lehoux, L., Yumashev, A., Meshkova, G., Lukiyanova, M. (2020). Crypto asset assessment models in financial reporting content typologies. Entrepreneurship and Sustainability Issues, 7(3): 2196-2212.

Noseleit, F. (2013). Entrepreneurship, structural change, and economic growth. Journal of Evolutionary Economics, 23(4): 735-766.

Weigmann, K. (2015). Lessons learned in Germany. EMBO Reports, 16(2): 142-146. 